\title{
Biblijne podstawy duchowości świętorodzinnej w nauczaniu sługi Bożego księdza Jana Berthiera, założyciela Zgromadzenia Misjonarzy Świętej Rodziny
}

Szukając biblijnych podstaw duchowości świętorodzinnej, należy znaleźć odpowiedź na pytanie: do jakich fragmentów Pisma Świętego odwoływał się ojciec Berthier, by przybliżyć uczniom i czytelnikom ducha Świętej Rodziny i kształtować w nich duchowość świętorodzinną? Ta ostatnia jest formą życia duchowego polegającego na naśladowaniu Chrystusa według wzoru Świętej Rodziny. Jan Berthier ${ }^{1}$, mówiąc o duchowości Świętej Rodziny, wskazywał głównie na cnoty, jakimi żyła Święta Rodzina i dopiero na ich podstawie tworzył biblijne fundamenty dla duchowości świętorodzinnej. W swoim wykładzie posługiwał się olbrzymią ilością cytatów ze Starego i Nowego Testamentu, co świadczy o doskonałej znajomości Pisma Świętego². Jednak jako komentator Pisma Świętego był Berthier spadkobiercą i świadkiem czasów, w których żył i pracował, a w jego życiu i duchowym rozwoju odbija się życie i doświadczenie Kościoła. Był to kapłan uformowany w okresie gwałtownego rozwoju badań biblijnych po stronie protestanckiej nacechowanych racjonalizmem i modernizmem, a takie postawy budziły nieufność po stronie katolickiej i były jej obce. Uczeni katoliccy stosowali egzegezę tradycyjną, zaś dla ogółu wierzących Pismo Święte było głównie źró-

${ }^{1}$ Jean Berthier urodził się 24 lutego 1840 roku w Chatonnay. 23 października 1958 roku wstąpił do wyższego seminarium w Grenoble, gdzie 5 kwietnia 1862 roku przyjął święcenia diakonatu. 14 lipca 1962 roku wstąpił do Zgromadzenia Misjonarzy z La Salette. We wrześniu 1862 roku przyjął święcenia kapłańskie w Grenoble. Pracował z wielkim oddaniem Matce Bożej z La Salette jako kaznodzieja i wychowawca młodzieży. Dostrzegł jednak potrzebę wychowania spóźnionych powołań dla celów misyjnych. Dlatego 28 września 1895 roku założył Zgromadzenie Misjonarzy Świętej Rodziny, które żyjąc duchem Świętej Rodziny, miało zająć się formowaniem do kapłaństwa ludzi, którzy z powodu wieku lub sytuacji ekonomicznej nie mogli podjąć studiów. Napisał wiele książek, wykazując się w nich ogromną wiedzą teologiczną i znajomością problemów człowieka. Zmarł 16 października 1908 roku w Grave.

${ }^{2}$ Por. J. Berthier, Sententiae et exempla biblica ex vetere et novo testamento excerpta et ordinata Ad usum concionatorum, moderatorum animarum et praesertim juniorum clericorum, seminariorumque alumnorum, La Salette 1886. 
dłem przykładów i cytatów³ . Ojciec założyciel, realizując wiernie wskazania Leona XIII, podkreślał olbrzymie znaczenie Pisma Świętego dla życia duchowego chrześcijanina, jednak przede wszystkim zwracał uwagę na te jego fragmenty, które odnoszą się do życia i rozwoju cnót chrześcijańskich ${ }^{4}$. Mówiąc o Świętej Rodzinie Berthier skupiał się głównie na cnotach, którymi się odznaczała. W przywoływanych tekstach biblijnych nasz założyciel podkreślał: posłuszeństwo woli Bożej, wierność i zaufanie, przykazanie miłości oraz kształtowanie ducha pokory i umartwienia.

\section{Posłuszeństwo woli Bożej}

Na samym początku analizowania biblijnych podstaw duchowości świętorodzinnej Berthier stawia cnotę posłuszeństwa. Uważa, że dzięki niej można ukazywać Świętą Rodzinę jako wzór wszelkich cnót. Rozpatrując temat posłuszeństwa woli Bożej, nasz autor nie przechodzi od razu do ewangelii dzieciństwa, ale swój wykład rozpoczyna od Księgi Rodzaju. Podkreśla, że wierne wypełnianie woli Bożej gwarantuje człowiekowi zachowanie godności dziecka Bożego pochodzącej z faktu stworzenia. Bóg uczynił go królem wśród stworzeń, bytem najdoskonalszym w świecie postrzeganym zmysłami, obdarzył godnością. Stworzył na swój obraz i podobieństwo, by ten mógł rozkazywać innym stworzeniom (por. Rdz 1,27) . Dzięki rozumowi i wolnej woli osoba ludzka może przekraczać świat materialny i rozwijać w sobie obraz ojcostwa Bożego zgodnie z nakazem Stwórcy (por. Rdz 1, 28). Musi jednak pamiętać, że wiązanie nadziei na bycie szczęśliwym z bytami przemijającymi jest krótkotrwałe, stanowi „marność nad marnościami” (Koh 1, 2)

W akcie stwórczym Bóg powołał do istnienia mężczyznę i kobietę (por. Rdz 2,18), by oddawali Mu chwałę i przekazywali życie. Dlatego „opuści człowiek ojca swego i matkę i złączy się ze swoją żoną, i będą oboje jed-

${ }^{3}$ Zob. A. Vaccari, Historia exegeseos, [w:] Institutiones Biblicae scholis accomodatae, t. 1: De S. Scriptura in universum, Romae 1929, s. 372-376; L. Stachowiak, Rozwój nauk biblijnych w XIX i początkach XX wieku (z ogólna charakterystyka okresu międzywojennego), [w:] Dzieje teologii katolickiej w Polsce, t. 3.1, Lublin 1976, s. 31-66; R. Rubinkiewicz, Historia egzegezy, [w:] Wstęp ogólny do Pisma Świętego, red. J. Szlaga, Poznań-Warszawa 1986, s. 281-284.

${ }^{4}$ Enc. Providentissimus Deus (18 listopada 1893) dawała jasne wskazania dla badaczy. Powodem jej napisania była liberalna biblistyka protestancka przesiąknięta racjonalizmem, podważająca naukę o natchnionym charakterze ksiąg biblijnych. Leon XIII podnosi w niej sprawę unowocześnienia studiów biblijnych, zastrzegając trzymanie się tekstu Wulgaty. Ponadto papież ten utworzył Papieska Komisję Biblijną 25 listopada 1902 roku, by czuwała nad prawowiernością badań biblijnych i organizowaniem studiów biblijnych.

${ }^{5}$ Por. J. Berthier, L'homme tel qu 'il doit être, Grave 1896, s. IX.

${ }^{6}$ Por. J. Berthier, L'art d'être heureux, Grave 1904, s. XII. 
nym ciałem" (Mk 10, 7)7 , a święty Paweł wyjaśnia, że miłość mężczyzny do żony powinna być ukształtowana na wzór miłości Chrystusa do swego Kościoła (por. Ef 5, 25). Niestety grzech pierwszych rodziców (por. Rdz 3, 1-24) spowodował nieodwracalne skutki w relacji Boga z człowiekiem. Bóg Ojciec jednak wychodzi naprzeciw ludzkiej nędzy i obiecuje Zbawiciela, który odkupi grzechy i otworzy znowu bramy nieba ${ }^{8}$.

W dalszej części swego wykładu Berthier podkreśla związek słów Bożych skierowanych bezpośrednio do Adama ze słowami przekazanymi „dzieciom Adamowym" za pośrednictwem proroków. Wspomina potop (por. Rdz 7, $6-8,18)$ i przymierze z Noem (por. $\operatorname{Rdz} 8,20-9,29)$. Przybliża postać patriarchy Abrahama i obietnicę, że z jego rodu wyjdzie Zbawiciel (por. Rdz 12n). Przytacza historię Józefa, syna Jakuba, sprzedanego w niewolę egipską (por. Rdz 37, 1-36), by zwrócić uwagę na Mojżesza, który wyprowadził naród Izraelski z niewoli i w imieniu tego narodu zawarł z Bogiem przymierze na górze Synaj (por. Wj 2n). Po Mojżeszu wymienia sędziów i królów, wśród nich Saula, Dawida i Salomona (por. 1 Sm 9, 1-1, Krl 11, 43). Omawiając historię narodu wybranego, założyciel podnosi także kwestię podziału za panowania Roboama (por. $1 \mathrm{Krl}$ 12n) i niewoli babilońskiej, podczas której Daniel określił czas przyjścia Mesjasza (por. Dn 7, 9-28). Podkreśla świętość ksiąg Starego Testamentu spisanych przez natchnionych pisarzy. Stwierdza, że naród żydowski wierzył nauce Pisma Świętego, a Jezus, Syn Boży, przyszedł, aby ją wypełnić i zawrzeć z człowiekiem nowe i ostateczne przymierze ${ }^{9}$. Berthier cytuje także słowa proroka Izajasza: „Oto Panna pocznie i porodzi Syna, i nazwie go imieniem Emmanuel” (Iz 7, 14), by przygotować miejsce dla tajemnicy wcielenia Syna Bożego ${ }^{10}$.

\section{POSŁUSZEŃSTWO WOLI BOŻEJ W TAJEMNICY WCIELENIA}

Kluczem do zrozumienia Świętej Rodziny w Nowym Testamencie jest wcielenie Słowa. Wokół niego gromadzą się Maryja i Józef, a także bracia Jezusa, krewni, „nowa rodzina” (Mt 12, 46-50; Mk 3, 31-35; Łk 8, 19-21). Wcielenie jest „zstąpieniem” Słowa w głąb ludzkiej rzeczywistości, na łono

${ }^{7}$ Por. J. Berthier, Kult i naśladowanie Świętej Rodziny, tłum. z francuskiego A. Bocian, Pelplin-Ciechocinek 2003, s. 166.

${ }^{8}$ Por. J. Berthier, Książka dla wszystkich, tłum. z francuskiego M. Łoś, Górka Klasztorna 1926, s. 36-37.

${ }^{9}$ Por. J. Berthier, Ksiązka, dz. cyt., s. 38-42; Jezus Chrystus: Spotkanie Boga z człowiekiem. Materiały formacyjne polskiej prowincji Misjonarzy Świętej Rodziny, red. A. Bajorski, Ciechocinek 2003, s. 66.

${ }^{10}$ Por. J. Berthier, Kult, dz. cyt., s. 215. 
rodziny. Filiacja Jezusa jest objawieniem, które rozpoczyna się od dziewiczego poczęcia i dopełnia się w proklamacji na krzyżu (por. Mk 15, 39)11.

Mówiąc o posłuszeństwie woli Bożej, Berthier odwołuje się również do postaci nowotestamentalnych. W swoich książkach często nawiązuje do ewangelii dzieciństwa. Opisuje moment zwiastowania (por. Łk 1, 26-35) i podkreśla posłuszeństwo Maryi, która z pełnym oddaniem i pokorą przyjmuje posłannictwo anioła (por. Łk 1,38). Mówi o nawiedzeniu świętej Elżbiety (por. Łk 1, 39) ${ }^{12}$ i akcentuje postawę obu kobiet, które z pokorą wypełniają wolę Boga (por. Łk 1, 43-44). Elżbieta wysławia Maryję: „Błogosławiona, któraś uwierzyła, że spełnią się słowa powiedziane ci od Pana” (Łk 1, 45). Maryja wysłuchuje tych słów w duchu pokory i wypowiada uroczyste „Magnificat” (Łk 1, 46-48). Założyciel przypomina również scenę ofiarowania w świątyni, podkreślając zapowiedź miecza, który przeniknie duszę Niepokalanej (por. Łk 2, 35) ${ }^{13}$.

Nasz autor wspomina także o świętym Józefie, którego Ewangelia nazywa mężem sprawiedliwym (por. Mt 1,9). Podkreśla trudny wybór Józefa i pochwala jego posłuszeństwo i zaufanie woli Bożej. „Józefie, synu Dawida, nie bój się wziąć do siebie Maryi, twej małżonki, albowiem z Ducha Świętego jest to, co się z Niej poczęło” (Mt 1, 20). Mówi o rodowodzie Józefa: „Jakub był ojcem Józefa, męża Maryi, z której narodził się Jezus zwany Chrystusem" (Mt 1,16). Następnie zauważa, że pasterze udali się z pośpiechem i „znaleźli Maryję, Józefa i Niemowlę, leżące w żłobie” (Łk 2, 16). Docenia odwagę Józefa, gdy „wziął w nocy Dziecię i Jego Matkę i udał się do Egiptu” (Mt 2,14). Podkreśla prawne ojcostwo Józefa według słów Ewangelii: „Jego Ojciec i Matka dziwili się temu, co o Nim mówiono" (Łk 2, 33) ${ }^{14}$.

Dużo miejsca poświęca także zgubieniu i odnalezieniu Jezusa podczas pielgrzymki do Jerozolimy. Podkreśla zdziwienie rodziców: „Synu, czemuś nam to uczynił...” (Łk 2, 48), mądrość Jezusa między uczonymi w Piśmie (por. Łk 2, 46) i fakt, że Jezus poszedł z rodzicami, wrócił do Nazaretu i był im posłuszny (por. Łk 2, 51). Dodaje za ewangelistą, że „Dziecię rosło i nabierało mocy, napełniając się mądrością, a łaska Boża spoczywała na Nim” (Łk 2, 49). Opis nazaretańskiej codzienności ojciec Berthier konkluduje stwierdzeniem zaczerpniętym od świętego Łukasza, według

${ }^{11}$ Por. L. da Campo, La Santa Familia nel Nuovo Testamento, [w:] Atti del I Congresso Internazionale sulla Sacra Famiglia, Barcelona 1993, s. 133.

${ }^{12}$ Por. J. Berthier, Kult, dz. cyt., s. 190.

${ }^{13}$ Por. tamże, s. 211-212.

${ }^{14}$ Por. tamże, s. 212-213. 
którego Jezus czynił postępy w mądrości, latach i łasce u Boga i u ludzi, a Maryja chowała w pamięci wszystkie te wspomnienia (por. Łk 2, 52) ${ }^{15}$.

Wcielenie Jezusa według Berthiera to wypełnienie woli Ojca polegające na zawarciu nowego i wiecznego przymierza Boga z człowiekiem. Wcielenie jest uwieńczeniem aktu stworzenia, gdyż przez człowieczeństwo Syna Bożego jednoczy ono wszystkie istoty stworzone z ich Stwórcą. Nasz autor określa wcielenie tak jak Ewangelia według św. Jana: „Słowo stało się ciałem” (J 1, 14). Człowiek sam nie był w stanie przebłagać Boga za swe winy, dlatego Bóg w swym miłosierdziu zesłał Syna, by przyjął na siebie wszystkie ludzkie grzechy i uśmierzył gniew Boży (por. $1 \mathrm{~J} 4,10)^{16}$. „Tak bowiem Bóg umiłował świat, że swego Jednorodzonego Syna dał, aby każdy, kto w Niego wierzy, nie zginął, ale miał życie wieczne" (J 3, 16). Potwierdza to sam Chrystus: „Moim pokarmem jest pełnić wolę mojego Ojca” (J 4, 34$)^{17}$.

Posłuszeństwo Jezusa Bogu Ojcu zawierają także słowa: „z nieba zstąpiłem nie po to, aby pełnić swoja wolę, ale wolę Tego, który Mnie posłał” (J 6, 38). W tym duchu Syn Boży przyjmuje ubogich, biednych, chorych. Przebacza Marii Magdalenie (por. J 8, 1-11), wskrzesza Łazarza (por. J 11, 1-44) ${ }^{18}$. Przypomina gody w Kanie Galilejskiej i pierwszy publiczny cud Jezusa uczyniony na prośbę Matki (por. J 2, 1-12), rozmnożenie chlebów (por. Mt 14, 13-21), poskromienie burzy (por. Mk 4, 35-41) oraz liczne uzdrowienia, wskrzeszenia, uwolnienia z mocy złych duchów. Podkreślając świętość ziemskiego życia Jezusa opartą na posłuszeństwie woli Boga Ojca, założyciel zauważa, że Jego uczynki i słowa były boskimi. Ich fenomen polegał na zgodności nauczania z czynem, co po śmierci potwierdzili nawet oprawcy: „prawdziwie, ten człowiek był Synem Bożym” (Mk 15, 39) ${ }^{19}$.

\section{POSŁUSZEŃSTWO WOLI BOŻEJ W TAJEMNICY ODKUPIENIA}

Doskonała realizacja cnoty posłuszeństwa widoczne jest szczególnie w misterium odkupienia. Omawiając misterium paschalne Jezusa Chrystusa, Berthier zauważa, że Zbawicielowi nie oszczędzono żadnego bólu, nawet tego duchowego, który rozumie jako ból wynikający z poczucia opuszczenia przez Ojca, wyrażony w słowach: „Boże mój, Boże mój, czemuś Mnie opuścił?” (Mk 15, 34). Jezus cierpiał także ból udręczonego serca z powodu cierpienia Matki i ucieczki apostołów. Pomimo to wypeł-

\footnotetext{
${ }^{15}$ Por. tamże, s. 77-78.

${ }^{16}$ Por. J. Berthier, Ksiażka, dz. cyt., s. 50.

${ }^{17}$ Por. J. Berthier, Kult, dz. cyt., s. 132.

${ }^{18}$ Por. tamże, s. 30; J. Berthier, Książka, dz. cyt., s. 48-50.

${ }^{19}$ Por. J. Berthier, Notre Seigneur Jésus Christ, ce que nous lui devons, La Salette 1889,
} s. $93-105$. 
nił jednak wolę Ojca: „Nie moja wola, lecz Twoja niech się stanie!” (Łk 22, 42). Syn Boży uczynił swą Matkę stojącą pod krzyżem opiekunką całej rodziny ludzkiej. Obiecał niebo skruszonemu łotrowi i zwrócił się do Ojca z prośbą o przebaczenie ludziom tej zbrodni: „Ojcze, przebacz im” (Łk 23, 33). Umierając w piątek po wypowiedzeniu słów: „Wykonało się” (J 19, 30), Jezus wypełnił swoje zadanie. Wola Boga nie ograniczyła się tylko do odkupieńczej śmierci Jezusa. Misterium zmartwychwstania Chrystusa jest wydarzeniem rzeczywistym, wypełnieniem obietnic Starego Testamentu (por. Łk 24, 26-27; 44-48). Berthier podkreśla historiozbawczy sens zmartwychwstania, zwracając uwagę na wyzwolenie z grzechu i otwarcie drogi do nowego życia (por. 1 Kor $15,20-22)^{20}$.

Do istoty królewskiej misji Jezusa Chrystusa należy Jego władza jako Prawodawcy i Sędziego. On jest „Królem królujących i Panem panujących" (1 Tm 6, 15), i nie ma innej władzy, jak tylko ta, która od Boga pochodzi. Jezus jest Królem nieba i ziemi. Jezus jest także Sędzią. Sąd Boży obejmie u końca czasów każdego człowieka. Wówczas sprawiedliwi zostaną zaproszeni do uczestnictwa w Jego królestwie: „Pójdźcie błogosławieni u Ojca mojego...” (Mt 25, 34), zaś ci, którzy nie chcą, by Jezus panował nad nimi, zostaną odrzuceni: „Idźcie precz ode Mnie, przeklęci...” (Mt $25,41)^{21}$. Berthier, podsumowując zagadnienie posłuszeństwa woli Boga, przytacza słowa samego Jezusa o tym, że „nie ten, kto Mi mówi Panie, Panie wejdzie do królestwa, ale ten, który wypełnia wolę Ojca” (Łk 6, 46) ${ }^{22}$.

Zagadnienie posłuszeństwa nasz autor rozciąga także na relacje międzyludzkie. Jako wypełnienie woli Bożej widzi również posłuszeństwo dzieci względem rodziców (por. Ef 6, 1; Kol 3, 20) ${ }^{23}$. Zaznacza, że Bóg obdarza szczególną łaską tych, których przeznacza na przełożonych na ziemi: rodziców, opiekunów, mistrzów, sprawujących władzę. Oni zaś zyskują prawo do szacunku synowskiego, który tłumaczy się mocą czwartego przykazania (por. Syr 3, 1-16) ${ }^{24}$.

Przypomina także słowa Jezusa do apostołów, a przez nich do wszystkich pasterzy Kościoła: „Jak Ojciec Mnie posłał, tak i Ja was posyłam” (J 20, 21), a także: „Ja jestem z wami przez wszystkie dni aż do skończenia świata" (Mt 28, 20). Przestrzega, że odrzucenie doktryny Kościoła jest równoznaczne $\mathrm{z}$ nieposłuszeństwem Bogu, wyparciem się wiary w słowo

\footnotetext{
${ }^{20}$ Por. J. Berthier, Kult, dz. cyt., s. 35.

${ }^{21}$ Por. J. Berthier, Notre Seigneur, dz. cyt., s. 159-162.

${ }^{22}$ Por. J. Berthier, Kult, dz. cyt., s. 136

${ }^{23}$ Por. tamże, s. 187.

${ }^{24}$ Por. J. Berthier, L'homme tel qu ,il doit être, Grave 1896, s. 140-142.
} 
Boże i z rezygnacją z możliwości zbawienia: „Kto was słucha, Mnie słucha, kto wami gardzi, Mną gardzi” (Łk 10, 16) ${ }^{25}$.

\section{Wiara i zaufanie}

Posłuszeństwo woli Bożej musi być oparte na wierze w Boga i zaufaniu Jego miłości. Ojciec założyciel podkreśla, że mimo obaw, niebezpieczeństw, ubóstwa i codziennych utrapień, jakie towarzyszyły życiu Świętej Rodziny, zachowywała ona ufność i pokój, przyjmując swój krzyż ze względu na Boga, któremu w ten sposób składała wynagrodzenie za grzechy świata. Zatem wszyscy, którzy swoje troski łączą z Jezusem, Maryją i Józefem, zostaną pocieszeni. Bóg, dopuszczając cierpienie, obdarza proporcjonalną do niego łaską. Cierpienie z miłości do Boga w wyrzeczeniu się siebie jest najpewniejszą gwarancją życia wiecznego (por. Rz 8, 17) ${ }^{26}$.

Wiara w kontekście życia wiecznego jest fundamentem i początkiem zbawienia. Obietnica Chrystusa odnosi się do tych, którzy modlą się z wiarą w Boże słowo (por. Mt 21, 22) ${ }^{27}$. Wiara odsłania zamysł Boga, by ofiarować się człowiekowi i pozwolić mu ujrzeć w Nim dobro najwyższe. Wiara jest zatem podstawą nadziei, dowodem prawdy, której nie widzimy, a której jesteśmy bardziej pewni niż prawdy potwierdzonej naocznie (por. Hbr 11, 1). Gwarantem tej pewności jest Jego słowo ${ }^{28}$.

Naturalną konsekwencją życia wiarą jest przestrzeganie praw Bożych (por. J 2, 17). Jezus czynił wolę Ojca, a wraz z Nim Maryja i św. Józef. Tak również powinny czynić rodziny chrześcijańskie: „Kto idzie za Mną, nie będzie chodził w ciemnościach” (J 8,12). Wiara uczy, że należy przyjąć słowo Boże, odwracać się od zła i ujrzeć krzyż jako drogę prowadzącą do prawdziwej przemiany duchowej. Ona wspiera ludzkie czyny, nadając im charakter nadprzyrodzony. Bez nich wiara pozostaje martwa (por. Jk 2, 17). Dobroć i wierność Boga inspirują nadzieję człowieka sprawiedliwego, by ufnie złożył w Boskich rękach wszystkie sprawy ziemskie z przekonaniem, że jest On Ojcem najczulszym. Kocha i obdarza miłosierdziem, bo nie jest obojętny na ludzkie potrzeby (por. 1 Kor 13,7$)^{29}$.

Konsekwencją wiary i zaufania pokładanego w Bogu jest wytrwałość w realizowaniu Jego woli. Podejmując zagadnienie wytrwałości, założyciel opiera się na słowach Chrystusa, by nie ustawać w modlitwie, i przypomi-

\footnotetext{
${ }^{25}$ Por. tamże, s. 119.

${ }^{26}$ Por. J. Berthier, Kult, dz. cyt., s. 237-240.

${ }^{27}$ Por. J. Berthier, La clé du ciel, La Salette 1904, s. 206-207.

${ }^{28}$ Por. J. Berthier, L'art, dz. cyt., s. 289-290.

${ }^{29}$ Por. tamże, s. 299-300.
} 
na przypowieść o natrętnej wdowie (por. Łk 18, 1-8). Bóg pragnie, by wytrwale zwracano się do Niego z prośbami w przeróżnych potrzebach (por. Mt 11, 12). Przykładem jest postawa kobiety kananejskiej, której nawet początkowo odmowna odpowiedź Jezusa nie pozbawiła ufności, wiary i siły do dalszej prośby (por. Mt 15, 21-28). Wytrwałość czyni człowieka niezachwianym w dobru i pozwala zachowywać spokój ducha: „Kto wytrwa do końca, ten będzie zbawiony” (Mt 10, 22). Berthier podkreśla, że w szkole Świętej Rodziny należy się uczyć wytrwałości w łasce i stałości w przeciwnościach, by nie utracić tego, co zdobyto pracą, ale otrzymać pełną zapłatę (por. $2 \mathrm{~J}, 8$ ). Zauważa, że gdyby sprawiedliwy odstąpił od swej sprawiedliwości i popełniał zło, naśladując wszystkie obrzydliwości, wtedy żaden z wykonywanych czynów nie będzie mu poczytany, ale umrze z powodu nieprawości, które popełnił (por. Ez 18, 24). Potwierdzają to słowa samego Jezusa, który przestrzegał, że „ktokolwiek przykłada rękę do pługa, a wstecz się ogląda, nie nadaje się do królestwa Bożego” (Łk 9, 62). Dlatego ważne jest wezwanie zawarte na kartach Apokalipsy św. Jana: „Bądź wierny aż do śmierci, a dam ci wieniec życia” (Ap 2, 10) ${ }^{30}$.

\section{Przykazanie miłości}

Po omówieniu posłuszeństwa woli Bożej, wiary i zaufania Bogu, Berthier przechodzi do analizy kolejnej podstawy biblijnej duchowości świętorodzinnej, jaką jest przykazanie miłości. Podkreśla, że miłość Boga i bliźniego może istnieć tylko razem. Tezę powyższą opiera na cytatach z Pisma Świętgo: „Ja śpię, lecz moje serce czuwa” (Pnp 5, 2); „przemawiajcie do siebie wzajemnie w psalmach, hymnach i pieśniach pełnych ducha, śpiewając i wysławiając Pana w waszych sercach” $(\text { Ef 5, 19) })^{31}$; „w trzech rzeczach upodobałem sobie, które są przyjemne Panu i ludziom: zgoda wśród braci, przyjaźń między sąsiadami oraz mąż i żona dobrze zgadzający się wzajemnie" (Syr 25, 1) $)^{32}$.

Refleksję nad istotą doskonałej miłości Boga Berthier rozpoczyna od przybliżenia motywów, dla których człowiek powinien podjąc taką relację ze Stwórcą. W akcie stworzenia Bóg zaprosił człowieka do miłości, a potem wezwał po ojcowsku: „Będziesz miłował Pana, Boga swego, całym swoim sercem, całą swoją duszą, całym swoim umysłem i całą swoją mocą" (Mk $12,30)$. Chrystus w czasie swej działalności apostolskiej przypomina, że jest to pierwsze i najważniejsze ze wszystkich przykazań. Drugi akt zewnętrzny

\footnotetext{
${ }^{30}$ Por. J. Berthier, Kult, dz. cyt., s. 241-242.

${ }^{31}$ Por. tamże, s. 143-145.

${ }^{32}$ Tamże, s. 169.
} 
polega na zaangażowaniu się w dzieła Boże. Wszelkie obowiązki i prace wykonywane zgodnie z wolą Bożą i pod działaniem Ducha Świętego dowodzą głębokiej świadomości osoby miłującej Boga, że człowiek na tyle pozostaje blisko Chrystusa, na ile postępuje według Jego nauki: „Moją Matką i moimi braćmi są ci, którzy słuchają słowa Bożego i wypełniają je” (Łk 8, 21).

Według Berthiera wyrazem autentycznej miłości jest zgoda na cierpienie. Taką miłość okazał Chrystus, przyjmując krzyż na swoje ramiona. Krzyż jest ludzkim przeznaczeniem od bólu narodzin przez łzy, smutek, pokusy i zmagania aż po trwogę umierania (por. Flp 3, 8-10). Nasz autor dostrzega jednak, że ewangelia jest dobrą nowiną, nowiną o zbawieniu. Dlatego sens życia widzi w perspektywie krzyża. Potwierdza to cytatami z Ewangelii według św. Jana: „Jak Mnie umiłował Ojciec, tak i Ja was umiłowałem” (J 15,9). „Nikt nie ma większej miłości od tej, gdy ktoś życie swoje oddaje za przyjaciół swoich” (J 15, 13). „A Ja, gdy zostanę nad ziemię wywyższony, przyciągnę wszystkich do siebie" $(\mathrm{J} 12,32)^{33}$.

Uzasadnienie potrzeby miłości bliźniego Ojciec Założyciel widzi w słowach listu świętego Jana: „Kto nie miłuje brata swego, którego widzi, nie może miłować Boga, którego nie widzi” (1 J 4, 20). Miłość Boga i bliźniego są jedną i tą samą cnotą. Kto jest niedoskonały w miłości bliźniego, jest niedoskonały w miłości Boga. Dusze, które dążą do doskonałości, powinny zatroszczyć się o rozwój miłości bliźniego ${ }^{34}$.

Odpowiedź na pytanie, jak miłować bliźniego, nasz autor znajduje w Ewangelii: „Abyście się wzajemnie miłowali, tak jak Ja was umiłowałem” (J 13, 34), aż po cierpienie i śmierć. Zauważa, że uniwersalną formułę miłości święty Jan ujmuje następująco: „Nie miłujmy słowem i językiem, ale czynem i prawdą" $(1 \mathrm{~J} 3,18)$. Dlatego każdy człowiek, dążąc do doskonałości, winien z gorliwością wypełniać swoje zadania z miłości do Boga i bliźniego ${ }^{35}$.

Jan Berthier uważa, że wewnętrzną zasadą miłości jest całkowite oddanie. Jednocząc się z Bogiem, człowiek odpowiada na Jego miłość, tak jak On na to zasługuje. „Jeśli Mnie kto miłuje, będzie zachowywał moją naukę, a Ojciec mój umiłuje go i przyjdziemy do niego, i będziemy u niego przebywać" $(\mathrm{J} 14,23)^{36}$. Brak miłości bliźniego wyklucza miłość Boga (por. $1 \mathrm{~J} 4,20)^{37}$. „Cokolwiek chcecie, aby ludzie wam czynili, i wy im czyń-

${ }^{33}$ Por. J. Berthier, Książka, dz. cyt., s. 51-52.

${ }^{34}$ Por. J. Berthier, L'état religieux, son excellence, ses avantages, ses obligations, ses privilèges, La Salette1893, s. 180-182.

${ }^{35}$ Por. tamże, s. 184-187.

${ }^{36}$ Por. J. Berthier, L'art, dz. cyt., s. XL.

${ }^{37}$ Por. J. Berthier, L'homme, dz. cyt., s. 195 
cie" $\left(\right.$ Mt 7, 12) ${ }^{38}$. Zachęca, by braciom i siostrom ukazywać szczere uczucia, unikać przejawów złości, zazdrości, niechęci. Podpowiada, by wspierać się wzajemnie w przeciwnościach i być gotowym do poświęcenia. Ceni wyżej miłość braterską niż dobra materialne (por. Ps 133,1) ${ }^{39}$. Swój wykład popiera słowami Jezusa: „Dawajcie, a będzie wam dane” (Łk 6, 39), „więcej szczęścia jest w dawaniu aniżeli w braniu” (Dz 20, 38), „szczęśliwi miłosierni, gdyż oni dostąpią miłosierdzia" (Mt 5, 7) ${ }^{40}$.

Według naszego autora doskonała miłość może istnieć na dwa sposoby. Pierwszy, podstawowy polega na wyrzuceniu z serca wszystkiego, co jest jej przeciwne. Do takiej miłości powołani są wszyscy ludzie. Nie każdy ją jednak posiada wskutek zaniedbania swoich obowiązków chrześcijańskich i rezygnacji z pogłębiania życia duchowego. Drugi sposób odnosi się do doskonałości, która nie tylko sprzeciwia się grzechowi ciężkiemu, ale także wszystkiemu, co przeszkadza całkowitemu oddaniu się duszy Bogu. Sposób ten najlepiej wyrażają słowa, skierowane do młodzieńca: „Jeśli chcesz być doskonały, idź, sprzedaj, co posiadasz, i daj ubogim, a będziesz miał skarb w niebie" (Mt 19, 21) ${ }^{41}$.

W zagadnienie doskonalenia się w miłości Bożej wpisana jest zdaniem Berthiera modlitwa, życie sakramentalne oraz praktyki pobożne wobec Jezusa, Maryi i Józefa. Zaleca on, by oddawać Bogu chwałę słowami doksologii: „Chwała Ojcu i Synowi, i Duchowi Świętemu...”. Postuluje, by zachęcać innych do wspólnotowego chwalenia Boga (por. Ef 5, 19) ${ }^{42}$. Uważa, że zobowiązanie chrześcijanina do okazywania Bogu wdzięczności swój najpełniejszy kształt przyjmuje w formie modlitwy, która uczy pokory i jednocześnie jest źródłem nowych łask (por. 1 Tym 2, 1) ${ }^{43}$. Przypomina, że Jezus jest nauczycielem modlitwy, który sam się modli, a następnie zachęca do niej swych uczniów. Także w niebie wstawia się za ludźmi przed Bogiem, gdy Kościół prosi Go o miłosierdzie (por. Rz 8, 34) ${ }^{44}$. Chrystus nauczył uczniów na ich prośbę Modlitwy Pańskiej (por. Łk 11, 1n). Jej słowa powinny napełnić człowieka miłością, gdyż przypominają o ludzkiej godności i każą zwracać się do Ojca z dziecięcą ufnością. Bóg ogarnia miłością

${ }^{38}$ Por. J. Berthier, Kult, dz. cyt., s. 172.

${ }^{39}$ Por. tamże, s. 268.

${ }^{40}$ Por. tamże, s. 191-192.

${ }^{41}$ Por. tamże, s. $80-82$.

${ }^{42}$ Por. J. Berthier, La clé, dz. cyt., s. XII-XIII.

${ }^{43}$ Por. Tomasz z Akwinu, Suma teologiczna, II-II, 83, a. 17; J. Berthier, La clé, dz. cyt., s. XVII-XVIII.

${ }^{44}$ Por. J. Berthier, Kult, dz. cyt., s. 145; tenże, La clé, dz. cyt., s. 61-64. 
do Syna wszystkich ludzi (por. J 17, 26), stąd nasz autor zachęca wszystkich do umiłowania Ojca i zawierzenia Mu całego życia ${ }^{45}$.

\section{Postawa pokory i umartwienia}

Omawiając biblijne podstawy duchowości świętorodzinnej dotyczące cnót względem samego siebie, Berthier korzysta z tekstów zarówno Starego, jak i Nowego Testamentu: „o ile wielki jesteś, o tyle się uniżaj, a znajdziesz łaskę u Pana” (Syr 3, 18). Podkreśla, że słowa te w pełni urzeczywistniły się w życiu Świętej Rodziny. Nikt nie miał takiej pokory jak Jezus, Maryja i Józef. Słów: „Kto się uniża, będzie wywyższany” (Mt 18, 4) nasz autor używa w kontekście Świętej Rodziny ${ }^{46}$.

W dalszej części swego nauczania Berthier podkreśla pokorę Jezusa, który jest „drogą i prawdą, i życiem” (J 14, 6), mistrzem w ukazywaniu, jak Boga uwielbiać i składać Mu dziękczynienie. Po Synu Bożym przytacza postaci Maryi i Józefa, którzy ukazali najpiękniejszy sposób okazania Bogu wdzięczności przez naśladowanie Jego cnót. Święta Rodzina swym życiem potwierdziła słowa zawarte natomiast na kartach Biblii: „Cóż masz, czego byś nie otrzymał? A jeśliś otrzymał, to czemu się chełpisz, tak jakbyś nie otrzymał?” (1 Kor 4, 7). „Pokorni natomiast posiądą ziemię i będą się rozkoszować wielkim pokojem" (Ps 37, 11) ${ }^{47}$.

Założyciel wielokrotnie powtarza, że pokora przestrzega przed zbytnią pewnością siebie i zaufaniem we własne możliwości (por. 1 Kor 10, 12). Człowiek, który opiera się jedynie na swoich siłach, przestaje odczuwać potrzebę bliskości Boga i nie szuka z Nim kontaktu. To zaś powoduje upadek w grzech. Gdy jednak człowiek w swojej pokorze odda się Bogu, wówczas otrzyma wsparcie, odeprze pokusy i osiągnie życie wieczne, jak tłumaczy Jezus w przypowieści o faryzeuszu i celniku (por. Łk 18, 9-17). Potwierdzają to również inne słowa Nowego Testamentu: „Bóg pysznym się sprzeciwia, a pokornych obdarza łaską” (Jk 4, 6), „kto się wywyższa, będzie poniżony, a kto się poniża, będzie wywyższony” (Mt 23, 12). Berthier zauważa, że pokora Maryi i Józefa była proporcjonalna do otrzymanych przez nich łask. Podkreśla także, że ta cnota obowiązuje wszystkich ${ }^{48}$.

Wraz z postawą pokory według naszego autora idzie łagodność. Opisując tę cnotę przytacza słowa proroka Izajasza: „Nie będzie wołał ani pod-

\footnotetext{
${ }^{45}$ Por. J. Berthier, Książka, dz. cyt., s. 372-373.

${ }^{46}$ Por. tamże, s. 211-213.

${ }^{47}$ Por. tamże, s. 203-205.

${ }^{48}$ Por. J. Berthier, La clé, dz. cyt., s. 214-217. Berthier nazywa pokorę fundamentem życia duchowego. Zajmuje się tym zagadnieniem w wielu książkach. Zob: L'art, dz. cyt., s. 229-231 i 287-289; L'état religieux, dz. cyt., s. 227-228; Kult, dz. cyt., s. 211-214.
} 
nosił głosu. Nie da słyszeć krzyku swojego na dworze. Nie złamie trzciny nadłamanej, nie zgasi knotka o nikłym płomyku" (Iz 42, 2-3). Podaje również owoce łagodności: „odpowiedź łagodna uśmierza zapalczywość” (Prz $15,1)$. Ponadto łagodność poskramia gniew, łagodzi nieporozumienia, porządkuje relacje międzyludzkie, ma moc jednoczenia wszystkich we wzajemnym szacunku. Ukazuje również skutki łagodności: „Błogosławieni cisi, albowiem oni na własność posiądą ziemię” (Mt 5, 5), oraz: „Błogosławieni, którzy wprowadzają pokój, albowiem oni będą nazwani synami Bożymi” (Mt 5, 9), gdyż odznaczają się szczególnym podobieństwem do Boga, który jest źródłem pokoju. Stwierdza, że o taką atmosferę powinny zabiegać wszystkie rodziny domowe i zakonne, ugruntowując pokój w duszach swoich członków (por. Ps 37, 11) ${ }^{49}$.

$\mathrm{Z}$ kolei inną cnotą uwalniającą serce od troski o sprawy doczesne jest zdaniem Berthiera umartwianie. Uważa on, że Święta Rodzina potrafiła wyrzec się wszystkiego, co nie było jej niezbędne, ale świadoma sensu swego powołania, weszła z pokorą na drogę krzyża (por. Mt 16, 24). Dlatego zaleca, by kształtować siłę charakteru u dzieci i młodzieży, aby umiały stawić czoło przeciwnościom i nie zaniedbywać praktyki ascezy, która umocni ciało i ducha w walce ze słabościami. Sam Jezus, który jest „cichy i pokorny sercem" (Mt 11, 29), uczy człowieka podnosić się z upadku przez pokorę: „Uniżył samego siebie, przyjąwszy postać sługi” (Flp 2, 7). Stąd zdaniem Berthiera na drodze doskonałości konieczne jest połączenie umartwienia z modlitwą. Doskonała modlitwa wymaga współbrzmienia z życiem i pracą modlącego się (por. Iz 58, 7-9). Jej wartość wzmacniają różne formy pobożności: post, pokuta i jałmużna, skrucha serca. Człowiek poddający się ascezie nie będzie zniewolony przez przyjemności doczesne, lecz będzie mógł zawsze wznieść swe serce do Boga (por. Łk 6, 37-38) ${ }^{50}$.

Podsumowując, należy podkreślić dużą znajomość Pisma Świętego przez ojca założyciela i umiejętne podawanie cytatów w zależności do omawianych treści. Dowodzi tego również wydana przez niego książka: Sententiae et exempla biblica ex vetere et novo testamento excerpta et ordinata Ad usum concionatorum, moderatorum animarum et praesertim juniorum clericorum, seminariorumque alumnorum (La Salette 1886). Biblijne podstawy duchowości świętorodzinnej opiera na zagadnieniu posłuszeństwa woli Bożej, miłości Boga i bliźniego oraz postawie pokory i umartwienia. Tematyka ta w pełni oddaje podstawową zasadę nauczania księdza Berthie-

${ }^{49}$ Por. J. Berthier, La clé, dz. cyt., s. 193-200.

${ }^{50}$ Por. Tomasz z Akwinu, Suma teologiczna, II-II, 32, a. 4; J. Berthier, La clé, dz. cyt., s. 143-149; 230-234; Konstytucje MSF 1985, nr 47. 
ra, którą jest naśladowanie Chrystusa poprzez realizowanie cnót na wzór Świętej Rodziny. Oparcie tej tematyki na bogatych źródłach staro- i nowotestamentalnych stanowi również doskonałą realizację nauczania Leona XIII, który w encyklice Providentissimus Deus wezwał do przywrócenia znaczenia Pismu Świętemu w życiu chrześcijańskim. Omawiając biblijne podstawy duchowości świętorodzinnej, nasz autor zachęca współczesne rodziny, by powierzyły się Świętej Rodzinie, co pomoże im dokładniej odczytywać i wypełniać wolę Bożą w codzienności, zaś oddanie się Jezusowi przez Maryję na wzór ofiarowania Jezusa Ojcu przez Maryję i Józefa w świątyni (por. Łk 2, 22-35) zapewni człowiekowi pośrednictwo Matki Bożej we wszystkich niedostatkach ${ }^{51}$.

Kazimierz Biskupi

ADAM JÓZEF SOBCZYK MSF

\section{Słowa kluczowe}

Biblia, Święta Rodzina, Jan Berthier, duchowość, posłuszeństwo, wola Boża, wiara, przykazanie miłości, pokora, umartwienie

\section{Summary}

Biblical basics of the Holy Family's dimension of Christian spirituality according to the teaching of God's Servant Jean Berthier, founder of the Congregation Missionaries of the Holy Family

The analysis of the biblical basics of the Holy Family's dimension of Christian spirituality drawn by Jean Berthier shows his impressive knowledge of the Holy Bible. God' Servant uses many quotations to show biblical grounds for Christ's imitation according to the pattern of the Holy Family. There are a few virtues of the Holy Family which deserve to be highlighted: trust and obedience to God's Will, love to God and to neighbor, humility and mortification. Berthier not only enumerates those virtues, but also encourages everyone to realize them in everyday life, such as the Holy Family did it.

\section{Keywords}

Bible, Holy Family, Jean Berthier, spirituality, obedience, divine will, faith, commandment of love, humility, mortification

${ }^{51}$ Por. J. Berthier, Wypowiedź w Święto Ofiarowania Pańskiego 1907 roku, [w:] P. J. Diesburg, A. Kuczera, Adnotationes, Grave 1905-1908, s. 5. Szerzej na temat tajemnicy Maryi w życiu ojca założyciela zob. J. M. Lombaerde, Un Apôtre de nos jours ou La vie et l'Esprit du TR. R. Père J. Berthier, Grave 1910, s. 257-273. 
